\title{
Phylogenetic Characterization of Culturable Antibiotic Producing Streptomyces from Rhizospheric Soils
}

\author{
Mobolaji Felicia Adegboye and Olubukola Oluranti Babalola*
}

Faculty of Agriculture, Science and Technology, Department of Biological Sciences, North-West University, South Africa

\begin{abstract}
Streptomyces spp. were isolated from rhizospheric soils collected from Ngaka Modiri Molema District, North West Province, South Africa. Ten of these bacterial isolates were found to exhibit broad spectrum antimicrobial activity against test organisms with varying degree of activity. The cultural characteristics of the bacterial isolates were consistent with that of the members of the genus Streptomyces. Molecular identification of the potent bacterial isolates was carried out by amplifying the 16S rDNA gene; this gave the expected size of $1.5 \mathrm{~kb}$ and was sequenced. Further computational analysis including BLAST search and phylogenetic analysis were performed to correlate the bacterial isolates with other species of the genera in the database library. The computational analysis of the amplified $16 \mathrm{~S}$ rDNA gene confirmed that the bacterial isolates are members of the genus Streptomyces with $89-100 \%$ sequence similarity. The phylogenetic analysis showed that the 10 bacterial isolates were divided into 3 major clusters with varying bootstrap values. The strain NWU195 formed a distinct phyletic line in the Streptomyces 16S rDNA gene tree suggesting a new strain. The $16 \mathrm{~S}$ rDNA sequences of the bacterial isolates was submitted to the GenBank under the accession numbers JX284398-JX284407. The 16S rDNA gene sequence analysis is a significant tool for phylogenetic analysis of Streptomyces spp.
\end{abstract}

Keywords: Streptomyces; Rhizosphere; Phylogenetic; Antimicrobial; $16 \mathrm{~S}$ rDNA

\section{Introduction}

Soil is a habitat for microorganisms and also serves as reservoir for their metabolites [1]. The genus Streptomyces is one of prominent soil inhabitant, comprising up to $90 \%$ of actinomycetes isolated from soil samples. Streptomyces is the largest and the most important genus in the order actinomycetales. The genus Streptomyces is prolific producers of bioactive secondary metabolites that have important applications both in medicine and agriculture $[2,3]$. In the history of drug discovery, majority of novel substances of microbial origin are isolated from Streptomyces, over two-thirds of all microbial antimicrobial agents are derived from them [4,5]. Many novel drugs have been developed from Streptomyces spp. including S. griseus, S. hygroscopicus, S. coelicolor, S. avermitilis, S. rochei, S. plicatus, S. fungicidicus, S. flaveus, and S. globisporus; belonging to different classes of antibiotics such as aminoglycosides, ansamycins, anthracyclines, glycopeptides, $\beta$-lactams, macrolides, nucleosides, peptides, polyenes, polyethers, and tetracyclines [6-8]. These organisms are of high biotechnological and commercial values; and continue to be routinely screened for new bioactive compounds [9-11]. Streptomyces spp. are aerobic, filamentous, Gram positive soil dwelling bacteria with high $\mathrm{G}+\mathrm{C}$ content in their genomic composition.

Pathogenic organisms are gaining resistance to existing clinical drugs either through acquire resistance (chromosomal mutation) or acquisition of genetic materials from other bacteria (vertical or horizontal transfer of genes) [12,13]. This uprising has rendered many onetime drug of choice ineffective against the pathogens [14]. Escalating numbers of antibiotic futile against pathogenic organisms is a worldwide scenario. There is a need to develop novel antibiotics with different mechanisms of action.

Various researches are taking place all over the world searching for antimicrobial agents to combat the menace of infectious disease agents. Despite the fact that soils have been continuously screened over 50 years for potent organisms there is still tendency of isolating novel antibiotic from terrestrial Streptomycetes. It has been reported that only a fraction of the antibiotics produced by Streptomyces strains have been discovered [15]. Some Streptomyces spp. possess more than 20 gene clusters devoted to the synthesis of secondary metabolites [16]. Determination of the nucleotide sequence of the $16 \mathrm{~S}$ rDNA gene is a well established standard method for the identification and phylogenetic classification of unknown organisms up to the species level. Our investigation was aimed to isolate and screen antibiotic producing Streptomyces from rhizospheric soils and evaluate their evolutionary linage for possible novel antimicrobial agent(s).

\section{Materials and Methods}

\section{Sampling area}

The study area covered the Ngaka Modiri Molema District in North West Province of South Africa (Figure 1). The latitude and longitude of the district is $25^{\circ} 55^{\prime} \mathrm{N}$ and $25^{\circ} 50^{\prime} \mathrm{E}$ respectively. It covered a total of $28,206 \mathrm{~km}^{2}$ area. Temperatures range from $17^{\circ} \mathrm{C}$ to $31^{\circ} \mathrm{C}\left(62^{\circ}\right.$ to $\left.88^{\circ} \mathrm{F}\right)$ in the summer and from $3^{\circ}$ to $21^{\circ} \mathrm{C}\left(37^{\circ}\right.$ to $\left.70^{\circ} \mathrm{F}\right)$ in the winter. The average rain fall is $360 \mathrm{~mm}$.

\section{Isolation of actinomycetes}

Isolation and enumeration of actinomycetes present in the soil sample was performed by serial dilution plate technique using starch casein agar, as described previously [17].

\section{Screening for antibiotic producing actinomycetes}

Determination of antimicrobial activities of pure actinomycetes

*Corresponding author: Olubukola Oluranti Babalola, Faculty of Agriculture, Science and Technology, Department of Biological Sciences, North-West University, South Africa, Tel: +27183892568; Fax: +27183892134; E-mail: olubukola.babalola@nwu.ac.za

Received November 12, 2012; Accepted December 19, 2012; Published December 21, 2012

Citation: Adegboye MF, Babalola OO (2013) Phylogenetic Characterization of Culturable Antibiotic Producing Streptomyces from Rhizospheric Soils. Mol Biol S1: 001. doi:10.4172/2168-9547.S1-001

Copyright: (c) 2013 Adegboye MF, et al. This is an open-access article distributed under the terms of the Creative Commons Attribution License, which permits unrestricted use, distribution, and reproduction in any medium, provided the original author and source are credited. 


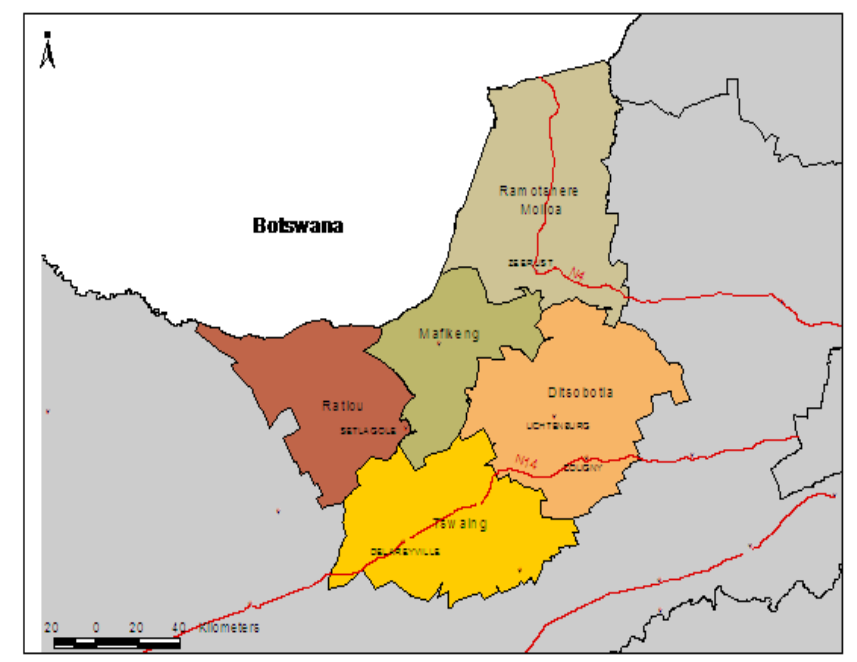

Figure 1: A map of Ngaka Modiri Molema district showing different localities where soil samples were collected.

cultures was performed by cross-streak method as described previously [18].

\section{Test organisms}

Staphylococcus aureus ATCC 29213, Streptococcus pyogenes ATCC 12344, E. coli ATCC 43478, Bacillus subtilis ATCC 11774, B. cereus ATCC 11778, Proteus mirabilis ATCC 49132, Enterococcus faecalis ATCC 14506, Shigella boydii ATCC 9207, Klebsiella pneumoniae ATCC 8308, Pseudomonas aeruginosa ATCC 10145 and Salmonella typhimurium ATCC 14208.

These typed cultures were obtained from the Microbial Biotechnology Group Culture Collection of the Biological Sciences Department, Faculty of Science, Agriculture and Technology, NorthWest University, South Africa.

\section{Cultural characteristics}

Pure bacterial isolates were characterized culturally following the protocol given by the international Streptomyces project (ISP) [19] growth on ISP-2 medium was recorded after incubation at $25^{\circ} \mathrm{C}$ for 14 days.

\section{Isolation of genomic DNA}

Actinomycete genomic DNA was isolated by a protocol previously described [20] with some modification. Cultures were grown in $10 \mathrm{ml}$ of Luria Bertani broth (Merck) in McCartney bottles for 7 days and then centrifuged at 10,000 rpm (Universal Z300K model centrifuge; HERMLE Labortechnik Germany) for $5 \mathrm{~min}$. The mycelial pellet was resuspended in $500 \mu \mathrm{l}$ of $5 \mathrm{M} \mathrm{NaCl}$ and transferred to a $2 \mathrm{ml}$ Eppendorf tube. The cells were centrifuged at $10,000 \mathrm{rpm}$ for $5 \mathrm{~min}$, and the pellet was resuspended in $1 \mathrm{ml}$ of $10 \mathrm{mM}$ Tris-HCl-1 mM EDTA ( $\mathrm{pH}$ 7.5) (TE) containing $20 \mathrm{mg}$ of lysozyme/ml and $20 \mathrm{mg}$ of RNase A/ $\mathrm{ml}$ and incubated at $37^{\circ} \mathrm{C}$ for $30 \mathrm{~min}$. Following incubation, $250 \mu \mathrm{l}$ of $0.5 \mathrm{M}$ EDTA, $250 \mu \mathrm{l}$ of TE containing $5 \mathrm{mg}$ of proteinase $\mathrm{K} / \mathrm{ml}$, and $100 \mu \mathrm{l}$ of $10 \%$ sodium dodecyl sulfate were added to each tube and incubated at $37^{\circ} \mathrm{C}$ for $1 \mathrm{~h}$. The tubes were mixed by inversion after the addition of $250 \mu \mathrm{l}$ of $5 \mathrm{M} \mathrm{NaCl}$. Immediately thereafter, $200 \mu \mathrm{l}$ of cetyltrimethylammonium bromide (CTAB) solution $(10 \%$ CTAB plus $0.7 \mathrm{M} \mathrm{NaCl}$ ) was added, and the tubes were heated in a $65^{\circ} \mathrm{C}$ water bath for $30 \mathrm{~min}$. Cellular debris was removed by centrifugation at 8,000 rpm for 5 and the supernatant solution was transferred to a new 2-ml microcentrifuge tube. Proteins and lipids were removed by the addition of 0.3 volume of phenol-chloroform, and the phases were mixed by inversion and centrifuged at $12,500 \mathrm{rpm}$ for $5 \mathrm{~min}$. The aqueous phase was transferred to a new tube, and the DNA was precipitated with an equal volume of isopropanol. After the genomic DNA was centrifuged, the pellet was rinsed with $70 \%$ ethanol to remove traces of salt. The supernatant was gently poured off and the pellets were dried under vacuum using Tomy Micro VacTM mv-100 (Tomy Medico, Japan) vacuum dryer. The DNA was resuspended in $50 \mu \mathrm{l}$ of TE and incubated at $65^{\circ} \mathrm{C}$ for $1 \mathrm{~h}$ to reconstitute the DNA, for immediate use or storage at $-20^{\circ} \mathrm{C}$.

\section{PCR amplification}

The 16S rDNA gene was amplified from genomic DNA obtained from bacterial cultures by PCR with previously described primer fD1 (5'-AGAGTTTGATCCTGGCTCAG-3') and rP2 (5'-ACGGCTACCTTGTTACGACTT-3') [21]. PCR was performed in a total volume of $50 \mu \mathrm{l}$ containing 30-50 ng DNA, $100 \mathrm{mM}$ each primer, $0.05 \mathrm{U} / \mu \mathrm{l}$ Taq DNA polymerase, $4 \mathrm{mM} \mathrm{MgCl}_{2}$, and $0.4 \mathrm{mM}$ of each dNTP. The amplification reaction was performed with a DNA Engine DYAD Peltier thermal cycler (BioRad, USA). The thermal cycling condition used was an initial denaturation at $96^{\circ} \mathrm{C}$ for $5 \mathrm{~min}$, followed by 30 cycles of denaturation at $96^{\circ} \mathrm{C}$ for $45 \mathrm{~s}$, annealing at $56^{\circ} \mathrm{C}$ for $30 \mathrm{~s}$ and extension at $72^{\circ} \mathrm{C}$ for $2 \mathrm{~min}$, followed by a final extension at $72^{\circ} \mathrm{C}$ for $5 \mathrm{~min}$. The PCR amplicons were analysed by electrophoresis in $1 \%(\mathrm{w} / \mathrm{v})$ agarose gel. The gel containing ethidium bromide $(10 \mu \mathrm{g}$ $\mathrm{ml}^{-1}$ ) was view under Syngene Ingenius Bioimager (UK) to confirm the expected size of the product. The remaining mixture was purified using NucleoSpin Gel and PCR Clean-up kit (Macherey-Nagel, Germany).

\section{Nucleotide sequence determination}

PCR purified products of the $16 \mathrm{~S}$ rDNA of the strains were analysed for nucleotide sequence determination by using ABI PRISM 3500XL DNA Sequencer (Applied Biosystems) at Inqaba Biotechnical Industrial (Pty) Ltd, Pretoria, South Africa. Nucleotide sequence of the $16 \mathrm{~S}$ rDNA of the strains were determined and compared for similarity level with the reference species of bacteria contained in genomic database banks, using the 'NCBI Blast' available at the ncbi-nlm-nih. gov website [22].

\section{Molecular taxonomy determined by sequences and phylogenetic analysis}

Phylogenetic and molecular evolutionary analyses were conducted using softwares. Nucleotide sequences were analyzed and edited by using BioEdit software [23]. The partial 16S rDNA gene sequences were used to search the GenBank database with the BlastN algorithm to determine relative phylogenetic positions. Multiple alignments of the sequences were carried out by Mafft program 6.864 [24] against corresponding nucleotide sequences retrieved from GenBank. Evolutionary distance matrices were generated as described by Jukes and Cantor [25]. Phylogenetic analyses was conducted using MEGA version 5.10 [26] and neighbour joining [27]; minimum evolution [28]; maximum likelihood; UPGMA and maximum parsimony [29] trees was constructed. The methods were used in order to expatiate on the phylogeny and for better comparison. The robustness of the tree topology was evaluated by bootstrap analysis [30] based on 1000 resamplings. Putative chimeric sequences were identified using the Chimera Buster 1.0 software. Manipulation and tree editing were carried out using TreeView [31]. 


\section{Nucleotide sequence accession numbers}

The $16 \mathrm{~S}$ rDNA gene sequences obtained in this study have been submitted to the GenBank database and assigned accession numbers indicated in parentheses, NWU4 (JX284398), NWU233 (JX284399), NWU49 (JX284400), NWU91 (JX284401), NWU110 (JX284402), NWU195 (JX284403), NWU204 (JX284404), NWU339 (JX284405), NWU100 (JX284406), and NWU14 (JX284407).

\section{Results}

\section{Isolation of actinomycetes}

Streptomyces spp. was isolated from the soil samples collected from different localities in Ngaka Modiri Molema District. The colonies of actinomycetes are recovered from different serial decimal dilution Petri dishes. The bacterial isolates have morphological characteristic that were consistent with members of the genus Streptomyces. The colonies appear dry, rough, coloured or not, adhering to the medium and presence of aerial and/or substrate mycelia. They are mended in the same isolation medium and incubated at $28^{\circ} \mathrm{C}$ during 7 days.

\section{Cultural characterization}

The Streptomyces isolates were studied for cultural characteristics (Table 1). Cultural characteristics of the bacterial isolates were derived on the basis of observations made after 21 days of incubation on ISP2. All the isolates growth varied from good to few. The colours of the mycelia were varied from greyish to brown. These characteristic morphological properties strongly suggested that isolates belonged to the genus Streptomyces.

\section{Screening of Streptomyces isolates}

Among them, 10 isolates distinguished due to their antibacterial activity against test organisms. These Streptomyces isolates exhibited broad spectrum antimicrobial activities. The results were tabulated in table 2. The following percentage of Streptomyces isolates exhibited inhibitory effect against the test organisms including: S. aureus (100\%), S. pyogenes (100\%), C. coli (90\%), B. subtilis (100\%), B. cereus $(90 \%)$, P. mirabilis (40\%), E. faecalis (90\%), S. boydii (70\%), K. pneumoniae (40\%), P. aeruginosa (30\%) and S. typhimurium (50\%). Three isolates exhibited high antibacterial activities against all the test organisms and appeared promising.

\section{Molecular identification of Streptomyces isolates}

A $1.5 \mathrm{~kb}$ fragment was amplified from the genomic DNA with the bacterial universal primers (F1R5) (Figure 2). Identification of the isolates was confirmed by computational analysis. The generic identification of Streptomycetes was performed by analysis of partial sequences of their $16 \mathrm{~S}$ rDNA gene. The partial nucleotide sequences of the $16 \mathrm{~S}$ rDNA gene of the isolates were compared with nucleotide database of NCBI web server through BLAST tool. The BLAST search inferred that the isolates were members of the GC-rich actinomycetales. The 16S rDNA gene sequence of different Streptomyces species was obtained by BLASTN search; however 24 strains of Streptomyces were selected based on high identity (\%) with good $\mathrm{E}$ value. Table 3 results shows that query sequences were best pairwise aligned with $16 \mathrm{~S}$ rDNA gene sequence of Streptomyces spp. with sequence similarity and identity ranged between $89-100 \%$, with E value of 0 .

\section{Phylogenetic analysis and Streptomyces spp. diversity}

The 10 potent Streptomyces isolates were subjected to sequencing and phylogenetic analysis. The $16 \mathrm{~S}$ rDNA sequences of 10 isolates were aligned with 24 Streptomycetes sequences obtained from GenBank data library; and Kitasatospora spp. as the out-group. The phylogenetic position of the isolates was evaluated by constructing phylogenetic trees using neighbour-joining (NJ), minimum evolution

\begin{tabular}{|c|c|c|c|c|}
\hline Isolate & Growth & Aerial mycelium & Substrate mycelium & Reverse colony colour \\
\hline NWU4 & Good & Grey & Yellowish brown & Yellowish brown \\
\hline NWU14 & Good & Grey & Light brown & Brown \\
\hline NWU49 & Good & Dark green & Light brown & Green \\
\hline NWU91 & Moderate & White & Yellow & Orange \\
\hline NWU100 & Few & Grey & Greyish yellow & Brown \\
\hline NWU110 & Moderate & Greyish green & Dark brown & Brown \\
\hline NWU195 & Good & White & Yellowish grey & Reddish orange \\
\hline NWU204 & Good & Grey & Light brown & Brown \\
\hline NWU233 & Moderate & Cream & Yellow & Brown \\
\hline NWU339 & Few & Greyish green & Brown & None \\
\hline
\end{tabular}

Table 1: Cultural characteristics of bacterial isolates on ISP-2 medium.

\begin{tabular}{|c|c|c|c|c|c|c|c|c|c|c|}
\hline \multirow[b]{2}{*}{ тмTest organisms } & \multicolumn{10}{|c|}{ Isolate codes } \\
\hline & NWU4 & NWU14 & NWU49 & NWU91 & NWU100 & NWU110 & NWU195 & NWU204 & NWU233 & NWU339 \\
\hline Pseudomonas aeruginosa ATCC 10145 & - & + & - & + & - & - & - & + & - & - \\
\hline Klebsiella pneumoniae ATCC 8308 & - & + & - & + & - & - & - & + & - & + \\
\hline Enterococcus faecalis ATCC 14506 & - & + & + & + & + & + & + & + & + & + \\
\hline Shigella boydii ATCC 9207 & - & + & - & + & - & + & + & + & + & + \\
\hline Proteus mirabilis ATCC 49132 & - & - & - & + & - & - & - & + & + & + \\
\hline Bacillus subtilis ATCC 11774 & + & + & + & + & + & + & + & + & + & + \\
\hline Bacillus cereus ATCC 11778 & - & + & + & + & + & + & + & + & + & + \\
\hline Streptococcus pyogenes ATCC 12344 & + & + & + & + & + & + & + & + & + & + \\
\hline Staphylococcus aureus ATCC 29213 & + & + & + & + & + & + & + & + & + & + \\
\hline Campylobacter coli ATCC 43478 & + & + & + & + & - & + & + & + & + & + \\
\hline Salmonella typhimurium ATCC 14208 & + & + & - & + & - & + & - & + & - & + \\
\hline
\end{tabular}

+=Activity; -=No activity

Table 2: Antibacterial activity of potent actinomycetes isolates against pathogenic organisms 


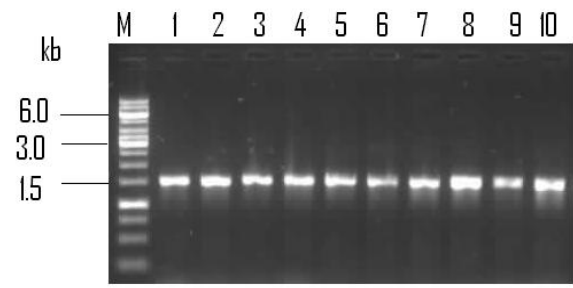

Figure 2: Amplified fragment of $16 \mathrm{~S}$ rDNA gene of the potent bacterial isolates 1-10 (1.5 kb); M: 1 kb Marker

\begin{tabular}{|c|c|c|c|c|c|}
\hline $\begin{array}{l}\text { Isolate } \\
\text { code }\end{array}$ & $\begin{array}{l}\text { Sequence } \\
\text { length (bp) }\end{array}$ & $\begin{array}{c}\text { Closest related } \\
\text { strain in database }\end{array}$ & $\begin{array}{c}\text { Accession } \\
\text { number }\end{array}$ & $\begin{array}{c}\text { Similarity } \\
(\%)\end{array}$ & E-value \\
\hline NWU4 & 1338 & S. globisporus & HQ995504 & 99 & 0 \\
\hline NWU14 & 1341 & $\begin{array}{c}\text { Uncultured } \\
\text { Streptomyces spp. }\end{array}$ & JQ358574 & 95 & 0 \\
\hline NWU49 & 1306 & $\begin{array}{l}\text { Streptomyces } \\
\text { viridosporus }\end{array}$ & NR 0438575 & 99 & 0 \\
\hline NWU91 & 1335 & Streptomyces rochei & JF486442 & 100 & 0 \\
\hline NWU100 & 1363 & $\begin{array}{l}\text { Streptomyces } \\
\text { hirsutus }\end{array}$ & AB184844 & 89 & 0 \\
\hline NWU110 & 1295 & $\begin{array}{l}\text { Streptomyces } \\
\text { emelensis }\end{array}$ & NR 043869 & 98 & 0 \\
\hline NWU195 & 1397 & $\begin{array}{l}\text { Streptomyces } \\
\text { hygroscopicus }\end{array}$ & FJ406123 & 95 & 0 \\
\hline NWU204 & 1308 & $\begin{array}{l}\text { Streptomyces } \\
\text { fungicidicus }\end{array}$ & AB184529 & 99 & 0 \\
\hline NWU233 & 1373 & $\begin{array}{l}\text { Streptomyces } \\
\text { espinosus }\end{array}$ & X80826 & 98 & 0 \\
\hline NWU339 & 1362 & $\begin{array}{l}\text { Streptomyces } \\
\text { griseus }\end{array}$ & AB184821 & 92 & 0 \\
\hline
\end{tabular}

Table 3: Results of $16 \mathrm{~S}$ rDNA gene sequence similarities of Streptomyces isolates and GenBank accession numbers using BLASTN Algorithm.

(ME), maximum likelihood (ML), maximum parsimony (MP) and UPGMA methods (Figures 3 and S1-S4). These methods consistently placed the bacterial isolates in different clade encompassing members of the genus Streptomyces with bootstrap support. Bootstrap values based on 1000 replications were listed as percentages at the branching points. The results from the different approaches show completely resolved, well-supported phylogeny of the 10 bacterial isolates with high resolution of all inner branches. Bacterial isolate NWU100 shows a low sequence similarity (89\%) with the closest related stain (S. prasinopilosus); this suggests that it's a novel Streptomyces spp. Phylogenetic analysis also revealed that the isolate NWU195 forms a distinct clade and the low sequence similarity values further suggest that NWU195 possibly belongs to a novel species with S. hygroscopicus as its closest relative. This is further supported by its taxonomic positions, confirmed by phylogenetic analyses (Figures 3 and S1-S4). Overall, the high-level branching in the phylogenetic trees agrees well with traditional systematic divisions, which group's organisms which belong taxonomically to the same family or the same genus into different species.

\section{Discussion}

Screening of nature for novel antimicrobial agents is a continuous process to match unending demand for bioactive substances in order to curtail the issues of infectious diseases. Nature has been a renowned source of bioactive compounds; this can be through screening of plants or microorganisms [1]. Microorganisms have proven to be an attractive source of bioactive compounds of industrial importance $[3,6]$. The unearthing of microbial secondary metabolites has a great capability in the development of industrial microbiology. The order actinomycetales, especially the genus Streptomyces are known to be inexhaustible producers of important microbial metabolites of medical and agricultural importance [32,33]. The terrestrial habitant is considered an excellent source for the exploration of Streptomyces with substantial potential. Several studies have previously reported on the isolation and diversity of Streptomyces from the terrestrial environment $[34,35]$. It was evident in this study that the genus Streptomyces is the dominant actinomycetes in rhizosphere. Similar studies carried out by other researchers' also show that Streptomyces spp. are predominant in the rhizosphere [36,37]. Previous research works have shown the number and diversity of the genus Streptomyces in the rhizospheric soils is in relation to the type and amount of exudates, and plant species [38]. It has been reported that root exudates stimulates the growth of actinomycetes in the rhizosphere [39]. The cultural characteristics of the bacterial isolates were similar to those describe by other researchers, this reveals that the isolates under study belong to the genus Streptomyces [34,40].

Majority of the novel antimicrobial agents are derived from soil borne actinomycetales. Streptomyces spp. are important group of organisms in the production of antimicrobial agents against pathogenic organisms. The bacterial isolates from the rhizospheric soils showed broad spectrum of antimicrobial activity against pathogenic organisms. The result of the screening reveals that most of the potent bacterial isolates were active against Gram positive organisms than Gram negative organisms. This can be attributed to the cell wall structure of the Gram negative organisms having an outer polysaccharide membrane carrying the structural lipopolysaccharide components. This makes the cell wall impermeable to lipophilic solutes [41]. The Gram positive organisms are more susceptible having only an outer peptidoglycan layer which is not an effective permeability barrier. The fact that the bacterial isolates exhibited broad spectrum of antimicrobial activity, this signify possible production of several antimicrobial compounds and/or production of compounds with multiple microbial targets. Several researchers have already reported Streptomyces to have biocontrol activity against pathogenic organisms $[9,42]$. This has been shown that the principle mechanism of this biological activity involved the production of secondary metabolites [6].

The identification of the bacterial isolates to the species level is vital since this provides informative insight about the organism, possible kind of bioactive compounds and if is novel or not [43]. The identification of the potent bacteria isolates in this study was based on $16 \mathrm{~S}$ rDNA gene sequence analysis. The sequence comparison of the bacterial isolates showed $89-100 \%$ identification similarities with $16 \mathrm{~S}$ rDNA gene sequence of the genus Streptomyces. Analysis of $16 \mathrm{~S}$ rDNA gene sequences has been proved to be a powerful method for phylogenetic characterization of microorganisms [44]. It helps to elucidate the evolutionary relationship among microorganisms. The phylogenetic relationship of the potent bacterial isolates to known Streptomyces spp. was first estimated through a blast search of the GenBank database. For a more robust analysis, the closest related strains were chosen for pairwise sequence comparison and construction of the phylogenetic trees. The bacterial isolates were grouped in distinct branches from each other. It was reported that strains which are clustered in different groups might produce different antimicrobial agents [45].

All the closest strains to the bacterial isolates have been linked to the production of one bioactive compound or more. S. globisporus had been described as a soil dwelling Gram positive bacteria with antibacterial, antifungal and antitumor activities [46,47]. Mutanolysin was isolated from S. globisporus, it is a muralytic enzyme that cleaves the $\beta$-N-acetylmuramyl- $(1 \rightarrow 4)-\mathrm{N}$-acetylglucosamine linkage of the 


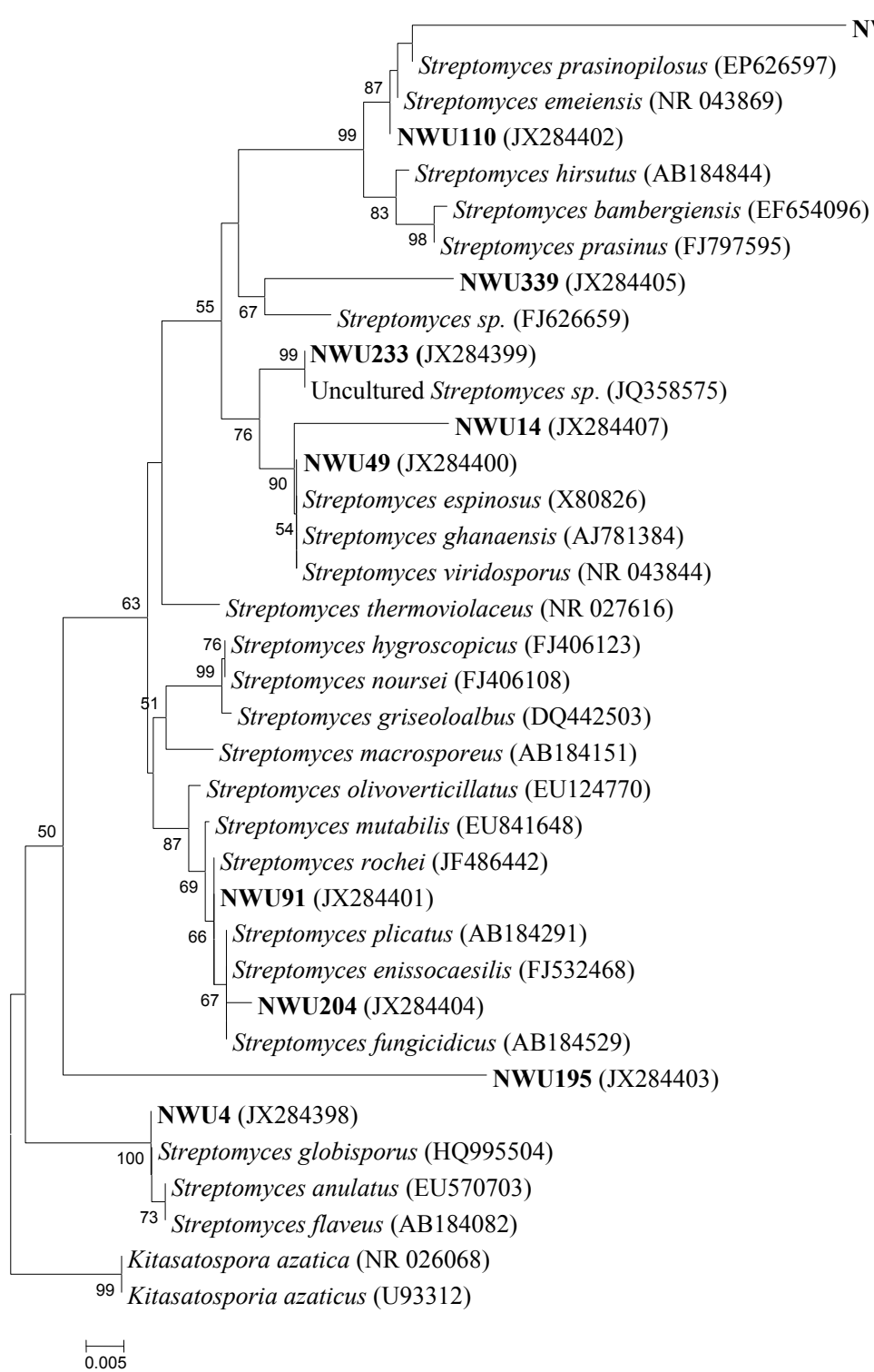

NWU100 (JX284406)

87

Streptomyces prasinopilosus (EP626597)

NWU110 (JX284402)

Streptomyces prasinus (FJ797595)

X80826)

Streptomyces ghanaensis (AJ781384)

Streptomyces viridosporus (NR 043844)

Streptomyces hygroscopicus (FJ406123)

Streptomyces noursei (FJ406108)

Streptomyces macrosporeus (AB184151)

Streptomyces olivoverticillatus (EU124770)

9

Streptomyces plicatus (AB184291)

Streptomyces enissocaesilis (FJ532468)

— NWU204 (JX284404)

Figure 3: Neighbour-joining tree of the bacterial isolates and representative species of the genus Streptomyces based on partial 16S rRNA gene sequences. Numbers at the nodes indicate the levels of bootstrap support based on 1000 resampled data sets. Only values greater than $50 \%$ are shown. The scale bar indicates 0.005 substitutions per nucleotide position.

bacterial cell wall polymer peptidoglycan-polysaccharide $[48,49]$. Volatiles from S. globisporus have been reported to act as antifungal agent against Penicillium italicum that cause blue mould infection on citrus [46].

A wide range of antimicrobial substances produced by Streptomyces spp. isolated from rhizosphere were been described, including Streptomyces spp. NRRL 30566 which bears 99\% 16S rDNA sequence similarity to S. griseus. Streptomyces spp. NRRL 30566 was reported to produced a novel antibiotic, kakadumycins which are DNA intercalating antibiotics that act by inhibiting DNA directed enzymatic RNA synthesis [50]. A novel compound Faeriefungin (polyene macrolides), was isolated from S. griseus, it was reported to have antibacterial, antifungal and insecticidal activities [51]. Moenomycin A is a novel antibiotic produced by S. ghanaensis, is a direct inhibitor of the enzyme peptidoglycan glycosyltransferases (transglycosylases); thereby inhibiting cell wall synthesis [52].

\section{Conclusion}

Our results suggest that Streptomyces spp. in the rhizosphere are diverse and these strains are suitable for natural product screening. The current molecular techniques seem to be a powerful tool in the identification bacterial isolates based on the characterization of the rDNA genes. Computational analyses are effective and reliable tools use to envisage the relatedness between the bacterial isolates and those in the GenBank database towards identification of antimicrobial compounds. It can be concluded that the use of phylogenetic analysis gives a better picture of the evolutionary relationship in the species level identification.

\section{Acknowledgements}

M.F.A. gratefully acknowledges financial support through a North-West University Postgraduate Bursary. O.O.B received financial support from National Research Foundation, South Africa. 
Citation: Adegboye MF, Babalola OO (2013) Phylogenetic Characterization of Culturable Antibiotic Producing Streptomyces from Rhizospheric Soils. Mol Biol S1: 001. doi:10.4172/2168-9547.S1-001

Page 6 of 7

\section{References}

1. Chin YW, Balunas MJ, Chai HB, Kinghorn AD (2006) Drug discovery from natural sources. AAPS J 8: E239-E253.

2. Atta HM, Bayoumi R, El-Sehrawi M, Aboshady A, Al-Humiany A (2010) Biotechnological application for producing some antimicrobial agents by actinomycetes isolates from Al-khurmah Governorate. Eur J Appl Sci 2: 98-107.

3. Demain AL, Sanchez S (2009) Microbial drug discovery: 80 years of progress. J Antibiot (Tokyo) 62: 5-16.

4. Ganesan A (2008) The impact of natural products upon modern drug discovery. Curr Opin Chem Biol 12: 306-317.

5. Newman DJ, Cragg GM (2007) Natural products as sources of new drugs over the last 25 years. J Nat Prod 70: 461-477.

6. Murray MY (2011) Microbial Secondary Metabolites: Comprehensive Biotechnology. (2ndedn), Academic Press, Burlington.

7. Baltz RH (2007) Antimicrobials from Actinomycetes. Back to the future. Microbe 2: $125-131$.

8. Watve MG, Tickoo R, Jog MM, Bhole BD (2001) How many antibiotics are produced by the genus Streptomyces? Arch Microbiol 176: 386-390.

9. Ali MA, Wali MA (2002) Deep vein thrombosis in non-anticoagulated head injury patients. West Afr J Med 21: 149-152.

10. Zotchev SB (2012) Marine actinomycetes as an emerging resource for the drug development pipelines. J Biotechnol 158: 168-175.

11. Chen KS, Lin YS, Yang SS (2007) Application of thermotolerant microorganisms for biofertilizer preparation. J Microbiol Immunol Infect 40: 462-473.

12. Skippington E, Ragan MA (2011) Lateral genetic transfer and the construction of genetic exchange communities. FEMS Microbiol Rev 35: 707-735.

13. Alanis AJ (2005) Resistance to antibiotics: are we in the post-antibiotic era? Arch Med Res 36: 697-705.

14. Arias CA, Murray BE (2009) Antibiotic-resistant bugs in the 21st century--a clinical super-challenge. N Engl J Med 360: 439-443.

15. Busti E, Monciardini P, Cavaletti L, Bamonte R, Lazzarini A, et al. (2006) Antibiotic-producing ability by representatives of a newly discovered lineage of actinomycetes. Microbiology 152: 675-683.

16. Guerra SM, Rodríguez-García A, Santos-Aberturas J, Vicente CM, Payero TD, et al. (2012) LAL regulators SCO0877 and SCO7173 as pleiotropic modulators of phosphate starvation response and actinorhodin biosynthesis in Streptomyces coelicolor. PLoS One 7: e31475

17. Morakchi H, Ayari A, Taok M, Kirane D, Cochet N (2009) Characterization of Streptomyces strain SLO-105 isolated from lake Oubeira sediments in North East Algeria. Afr J Biotechnol 8: 6332-6336.

18. Oskay M (2009) Antifungal and antibacterial compounds from Streptomyces strains. Afr J Biotechnol 8: 3007-3017.

19. Shirling EB, Gottlieb D (1966) Methods for characterization of Streptomyces species. Int J Syst Bacteriol 16: 313-340.

20. Magarvey NA, Keller JM, Bernan V, Dworkin M, Sherman DH (2004) Isolation and characterization of novel marine-derived actinomycete taxa rich in bioactive metabolites. Appl Environ Microbiol 70: 7520-7529.

21. Weisburg WG, Barns SM, Pelletier DA, Lane DJ (1991) 16S ribosomal DNA amplification for phylogenetic study. J Bacteriol 173: 697-703.

22. Altschul SF, Gish W, Miller W, Myers EW, Lipman DJ (1990) Basic loca alignment search tool. J Mol Biol 215: 403-410.

23. Hall TA (1999) BioEdit: a user-friendly biological sequence aligment editor and analysis program for Windows 95/98/NT. Nucleic Acids Symp Ser 41: 95-98.

24. Katoh K, Toh H (2010) Parallelization of the MAFFT multiple sequence alignment program. Bioinformatics 26: 1899-1900.

25. Jukes TH, Cantor CR (1969) Evolution of protein molecules: Mammalian Protein Metabolism. (3rdedn), Academic Press, New York.

26. Tamura K, Peterson D, Peterson N, Stecher G, Nei M, et al. (2011) MEGA5 molecular evolutionary genetics analysis using maximum likelihood evolutionary distance, and maximum parsimony methods. Mol Biol Evol 28: 2731-2739.
27. Saitou N, Nei M (1987) The neighbor-joining method: a new method for reconstructing phylogenetic trees. Mol Biol Evol 4: 406-425.

28. Rzhetsky A, Nei M (1992) A simple method for estimating and testing minimum evolution trees. Mol Biol Evol 9: 945-967.

29. Fitch WM (1986) An estimation of the number of invariable sites is necessary for the accurate estimation of the number of nucleotide substitutions since common ancestor. Prog Clin Biol Res 218: 149-159.

30. Felsenstein J (1985) Confidence limits on phylogenies: an approach using the bootstrap. Evol 39: 783-791.

31. Page RD (1996) TreeView: an application to display phylogenetic trees on personal computers. Comput Appl Biosci 12: 357-358.

32. Raja A, Prabakarana P (2011) Actinomycetes and drug-an overview. American J Drug Discovery Dev 1: 72-84.

33. Lam KS (2006) Discovery of novel metabolites from marine actinomycetes Curr Opin Microbiol 9: 245-251.

34. Rifaat HM, Nadia H, Abd El Naser, Helmy SM, Ali AM (2006) Taxonomical studies on certain streptomycetes exhibiting antimicrobial activity isolated from Egyptian soils. J Cult Collect 5: 25-34.

35. Oskay A, Tamer AU, Azeri C (2004) Antibacterial activity of some actinomycetes isolated from farming soils of Turkey. Afr J Biotechnol 3: 441-446.

36. Khamna S, Yokota A, Peberdy JF, Lumyong S (2010) Indole-3-acetic acid production by Streptomyces sp. isolated from some Thai medicinal plant rhizosphere soils. EurAsia J Biosci 4: 23-32.

37. Su A, Ting Y, Hoon S, Wai MK (2009) Isolation and characterization of actinobacteria with antibacterial activity from soil and rhizosphere soil. Austr J Basic Appl Sci 3: 4053-4059

38. Bais HP, Weir TL, Perry LG, Gilroy S, Vivanco JM (2006) The role of root exudates in rhizosphere interactions with plants and other organisms. Annu Rev Plant Biol 57: 233-266.

39. Bertin C, Yang X, Weston LA (2003) The role of root exudates and allelochemicals in the rhizosphere. Plant Soil 256: 67-83.

40. Arunachalam R, Wesely EG, George J, Annadurai G (2010) Novel approaches for identification of Streptomyces noboritoensis TBG-V20 with cellulase production. Curr Res Bacteriol. 3: 15-26.

41. Willey JM, Sherwood LM, Woolverton CJ (2010) Prescott's Microbiology. (7thedn), McGraw-Hill, New York.

42. Srividya S, Thapa A, Bhat DV, Golmei K, Dey N (2012) Streptomyces sp. 9p as effective biocontrol against chilli soilborne fungal phytopathogens. Euro $J$ Exp Bio 2: 163-173.

43. Adegboye MF, Babalola OO (2012) Taxonomy and ecology of antibiotic producing actinomycetes. Afr J Agricul Res 7: 2255-2261.

44. Thenmozhi M, Kannabiran K (2010) Studies on isolation, classification and phylogenetic characterization of novel antifungal Streptomyces sp. VITSTK7 in India. Curr Res J Biol Sci 2: 306-312.

45. Intra B, Mungsuntisuk I, Nihira T, Igarashi Y, Panbangred W (2011) Identification of actinomycetes from plant rhizospheric soils with inhibitory activity agains Colletotrichum spp., the causative agent of anthracnose disease. BMC Res Notes 4: 98

46. Li Q, Ning P, Zheng L, Huang J, Li G, et al. (2010) Fumigant activity of volatiles of Streptomyces globisporus JK-1 against Penicillium italicum on Citrus microcarpa. Postharvest Biol Technol 58: 157-165.

47. Ostash B, Rebets Y, Yuskevich V, Luzhetskyy A, Tkachenko V, et al. (2003) Targeted disruption of Streptomyces globisporus IndF and IndL cyclase genes involved in landomycin E biosynthesis. Folia Microbiol (Praha) 48: 484-488.

48. Shiba T, Harada S, Sugawara H, Naitow H, Kai Y, et al. (2000) Crystallization and preliminary $\mathrm{X}$-ray analysis of a bacterial lysozyme produced by Streptomyces globisporus. Acta Crystallogr D Biol Crystallogr 56: 1462-1463.

49. Brönneke V, Fiedler F (1994) Production of Bacteriolytic Enzymes by Streptomyces globisporus Regulated by Exogenous Bacterial Cell Walls. Appl Environ Microbiol 60: 785-791.

50. Castillo U, Harper JK, Strobel GA, Sears J, Alesi K, et al. (2003) Kakadumycins, novel antibiotics from Streptomyces sp NRRL 30566, an endophyte of Grevillea pteridifolia. FEMS Microbiol Lett 224: 183-190. 
Citation: Adegboye MF, Babalola OO (2013) Phylogenetic Characterization of Culturable Antibiotic Producing Streptomyces from Rhizospheric Soils. Mol Biol S1: 001. doi:10.4172/2168-9547.S1-001

Page 7 of 7

51. Nair MG, Putnam AR, Mishra SK, Mulks MH, Taft WH, et al. (1989) Faeriefungin: a New board-spectrum antibiotic from Streptomyces griseus var. autotrophicus. J Nat Prod 52: 797-809.
52. Ostash B, Makitrinskyy R, Walker S, Fedorenko V (2009) Identification and characterization of Streptomyces ghanaensis ATCC14672 integration sites for three actinophage-based plasmids. Plasmid 61: 171-175 